\title{
Meteorological Drought Characterization Using Effective Drought Index (EDI) for Banswara District (Rajasthan), India
}

\author{
Chandra Kishor Kumar*, V.K. Chandola and Ranjeet Kumar \\ Department of Farm Engineering, Institute of Agricultural Sciences, BHU, \\ Varanasi - 221 005, UP, India \\ *Corresponding author
}

\section{Keywords}

Meteorological drought, EDI, Drought severity

Article Info

Accepted:

24 August 2018

Available Online:

10 September 2018

\section{A B S T R A C T}

The agricultural drought has become a major concern worldwide because of its severe effect on the productivity of rain-fed crops and direct effect on service as well as per capita income. These agricultural droughts occur due to short-term moisture stresses. This work was carried out to analyze droughts in the Banswara region of Rajasthan using Effective Drought Index (EDI). Out of the 11 rain gauge station selected in the study, it was found that according to EDI, a meteorological drought of maximum severity -34.15 occurred for the duration of September 1989 to June 1991 which was of the longest period (22 months) in the study area falling under Sajjangarh rain gauge station. The drought having a maximum intensity of -2.13 , occurred in between July 1979 to May 1980, with a severity of -23.46 in the area under Bhungra rain gauge station. The maximum and a minimum number of extreme drought which occurred in Loharia and Arthuna rain gauge station were respectively 10 and 2 . A maximum number of 19 severe droughts and 59 moderate droughts occurred in Kushalgarh and Bagidora area respectively and a minimum number of one severe drought and 28 moderate droughts occurred in Banswara and Loharua rain gauge stations respectively. The maximum and a minimum number of 65 and 42 drought events occurred in Kushalgarh and Shergarh rain gauge station respectively. The rising trend of meteorological drought severity was found in the study area.

\section{Introduction}

Drought is a normal recurring feature of earth's climate, it has a peculiar slow onset and disastrous, long-lasting impacts; it affects more people than any other form of natural disaster. It is characterized in terms of the spatial extension, intensity, and duration (Drought Manual; Govt. of India, 2009). Generally, rainfall deficiencies over a long time period lead to severe droughts events (Wilhite and Knutson, 2008). Mainly four types of droughts are observed, meteorological (lack of precipitation), agricultural (lack of root zone soil moisture), hydrological (drying of surface water storage), socio-economic drought (lack of water supply for socioeconomic purpose) and these drought types are generally interlinked with each other (Sigdel and Ikeda, 2010). Meteorological drought is the situation when there is a considerable decrease from the normal precipitation amount over a particular region during an extended period of time. 
Agricultural drought plays a major role in the economy of agrarian countries like India where more than $68 \%$ people are dependent upon agriculture. About $16 \%$ of India's total area is drought-prone and about 50 million people are annually affected by drought (Dutta et al., 2015). The drought-prone areas of the country are mainly confined to western and peninsular India-mainly arid, semi-arid, and sub-humid regions. The arid tract of the western part of India is under threat of severe droughts due to paucity and abnormality of rainfall and severe climatic characteristics (Jain et al., 2010). The Effective Drought Index (EDI) in daily and monthly time steps, characterizes drought severity superior than any other index (Pandey et al., 2008). Kar et al., (2016) studied the drought severity using EDI for Bundelkhand region and found a gradually increasing severity. Morid et al., (2006) used EDI, which is able to detect the onset and spatiotemporal variation of drought consistently so the EDI was found to be more responsive to the emerging drought and hence preferred. In India, $80 \%$ of annual rainfall comes from southwest monsoon, and is very important for the whole country, especially for the low rainfall belts like Rajasthan state. Any kind of deficiency in monsoon, mostly because of climate change causes higher frequencies of droughts in these areas as high as once in every four years (Gupta et al., 2011). In the present research work, the effective drought index is used to characterize and study the meteorological drought scenario of Banswara district for helping the decision makers and planners for efficient management of water resources in the area.

\section{Materials and Methods}

\section{Study area}

The study has been carried out in Banswara district of Rajasthan; it is situated in the southern-most part, it has an area of 5037 sq. $\mathrm{km}$., which is $1.47 \%$ of a total geographical area and it is surrounded on, the east and southeast by Madhya Pradesh, on the southwest by Gujarat, and on the west by Dungarpur district the north by Udaipur district, on the northeast by Pratapgarh district. Banswara is located at $23.11^{\circ} \mathrm{N}$ to $23.56^{\circ} \mathrm{N}$ latitudes and $73.58^{\circ} \mathrm{E}$ to $74.49^{\circ} \mathrm{E}$ longitudes. Its elevation above mean sea level is about 302 m. (District Profile data, Banswara, Rajasthan). It lies in the Mahi River basin, the Mahi flows north through the district from its origin in the Vindhya Range of Madhya Pradesh, entering the district from the southeast and flowing north towards the northern end of the district, where it turns southwest to form the boundary between Banswara and Dungarpur districts before entering Gujarat and emptying into the Gulf of Cambay.

\section{Data availability}

For carrying out the drought study, the daily rainfall data of 35 years from 1974 to 2008 of eleven rain gauge stations situated around the Banswara district was considered. The rain gauge stations were as follows: Banswara, Garhi, Kushalgarh, Danpur, Shergarh, Arthuna, Loharia, Bhungra, Sajjangarh, and Ghatoland Bagidora. For this purpose, the rainfall data was collected from the Water Resources Department, Government of Rajasthan, which was available online at http://www.indiawaterportal.org. Table 1, depicts average rainfall data in $\mathrm{mm}$ for eleven rain gauge stations with their corresponding latitude and longitude.

\section{Meteorological drought characteristics evaluation based on effective drought index}

In the present study, the Effective Drought Index (EDI) developed by Byun et al., (1999) is used to analyse the drought severity by using the monthly precipitation data. The EDI 
is the ratio of the precipitation required for a return to normal (PRN) to the standard deviation of PRN, so it is called as the function of PRN. In monthly analysis, the calculation steps for EDI are discussed as follows:

$\mathrm{EPi}=\sum_{n=1}^{i} \frac{\sum_{m=1}^{\mathrm{n}} P_{m}}{n}$

Where, EPi is the effective precipitation parameter $(\mathrm{mm}), \mathrm{Pm}$ is the effective precipitation in (m-1) months before the current month $(\mathrm{mm})$, i represents the duration of the preceding period (months), $\mathrm{n}$ is the total number of periods before the current month (months).

The mean of EP for each month (MEP) are calculated and the EP values are converted to deviations from the mean (DEP) by subtracting it from EP values.

$\mathrm{DEP}=\mathrm{EP}-\mathrm{MEP}(2)$

EP is effective precipitation and MEP is the mean of each month's EP. Precipitations required for a return to normal (PRN) values were calculated as a function of DEP using the relation:

$\mathrm{PRNj}=\frac{\frac{D E P_{j}}{\sum_{n=1}^{j} \frac{1}{n}}}{(3)}$

$\mathrm{j}$ is actual duration over which precipitation deficit is accumulated, The summation term $(1 / n)$ is the sum of the reciprocals of all the months.

$\mathrm{EDIj}=\frac{\operatorname{PRN}_{j}}{\operatorname{std}\left(P R N_{j}\right)}(4)$

Std (PRNj) is the standard deviation of each month's PRN. The meteorological drought severity classification based on EDI values as per the range given by Byun et al., (2010) is given in Table 2 is used to identify its severity.

\section{Results and Discussion}

\section{Evaluation of meteorological drought characteristics}

The Effective Drought Index has been used for evaluating the meteorological drought scenario in the Banswara region. The temporal variation of the drought characteristics at Banswara, Garhi, Kushalgarh, Danpur, Shergarh, Arthuna, Loharia, Bhungra, Sajjangarh, Ghatoland and Bagidoraare depicted in Figure 1 to 11 . The declining EDI value observed from the analysis signifies an increasing drought severity for the study area. The temporal variation of drought characteristics including its onset, termination, duration as well as its severity has been discussed as follows.

A number of drought events faced at all the eleven rain gauge stations have been analyzed and the results are given in Table 3. It has been observed that extreme drought events occurred at Shergarh, Arthuna Bhungra and Loharia rain gauge station which are 3, 2, 9 and 10 respectively. A maximum number of 19 severe drought events occur in Kushalgarh and lowest at Banswara which is only one. The maximum moderate drought occurs at Bagidora which comes to be 59 and a minimum of 28 at Loharia rain gauge station. The total maximum numbers of 65 drought events occur in Kushalgarh and minimum in 42 at Shergarh rain gauge station.

The meteorological drought characteristics, including onset, termination, duration, severity and intensity based on the EDI have been evaluated for Banswara, Garhi, Kushalgarh, Danpur, Shergarh, Arthuna, Loharia, Bhungra, Sajjangarh, Ghatol and Bagidora rain gauge station and are given in Table 4. 
Fig.1 Temporal variation of meteorological drought at Banswara station

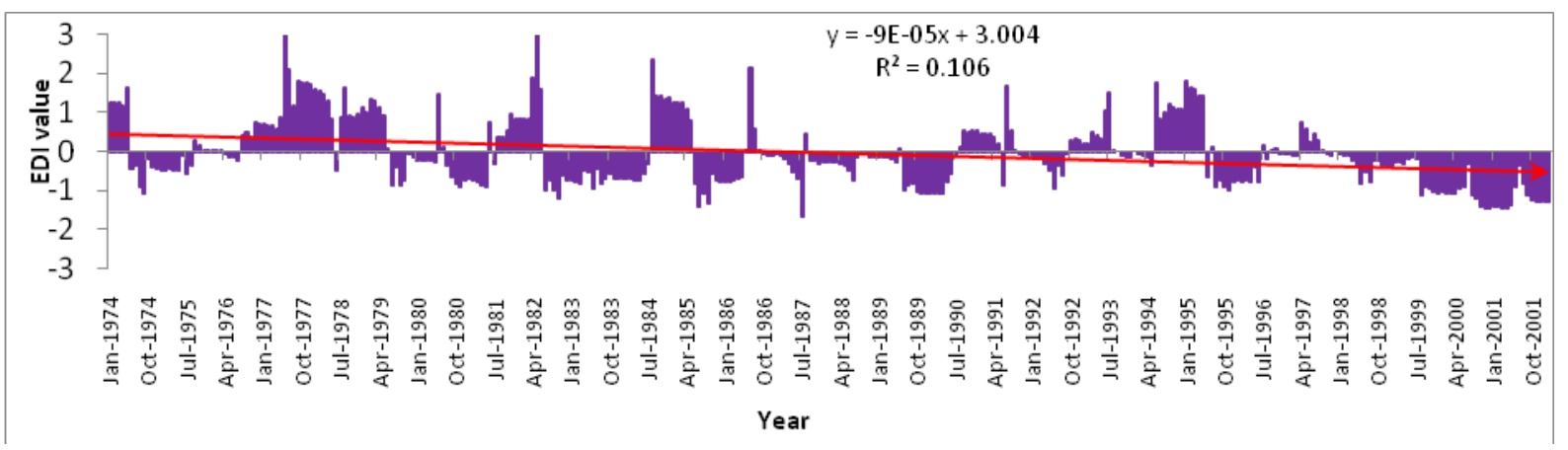

Fig.2 Temporal variation of meteorological drought at Garhi station

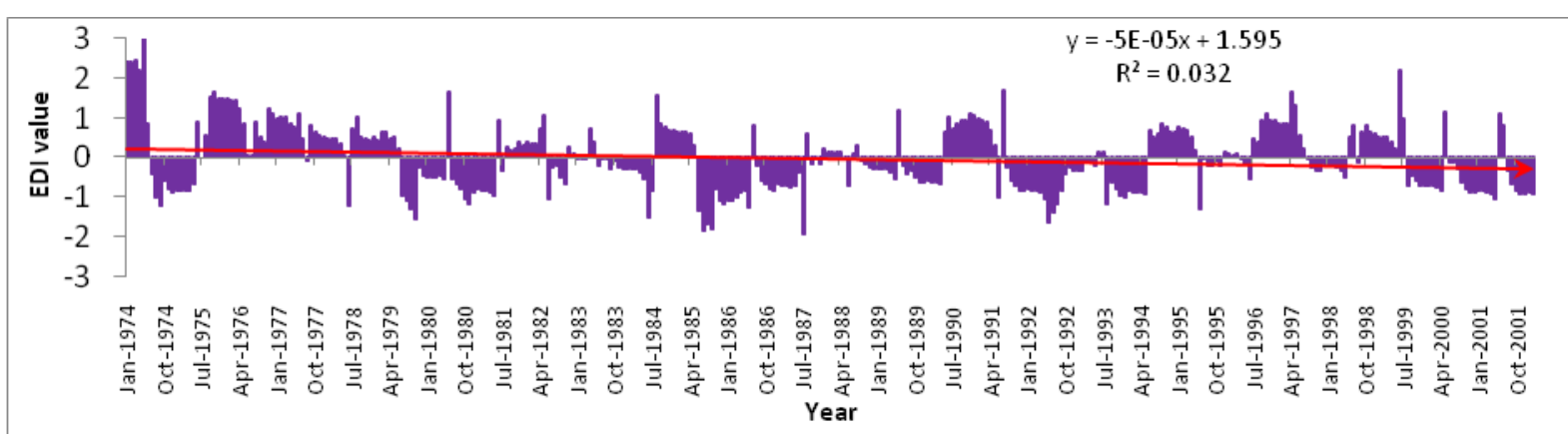

Fig.3 Temporal variation of meteorological drought at Kushalgarh station

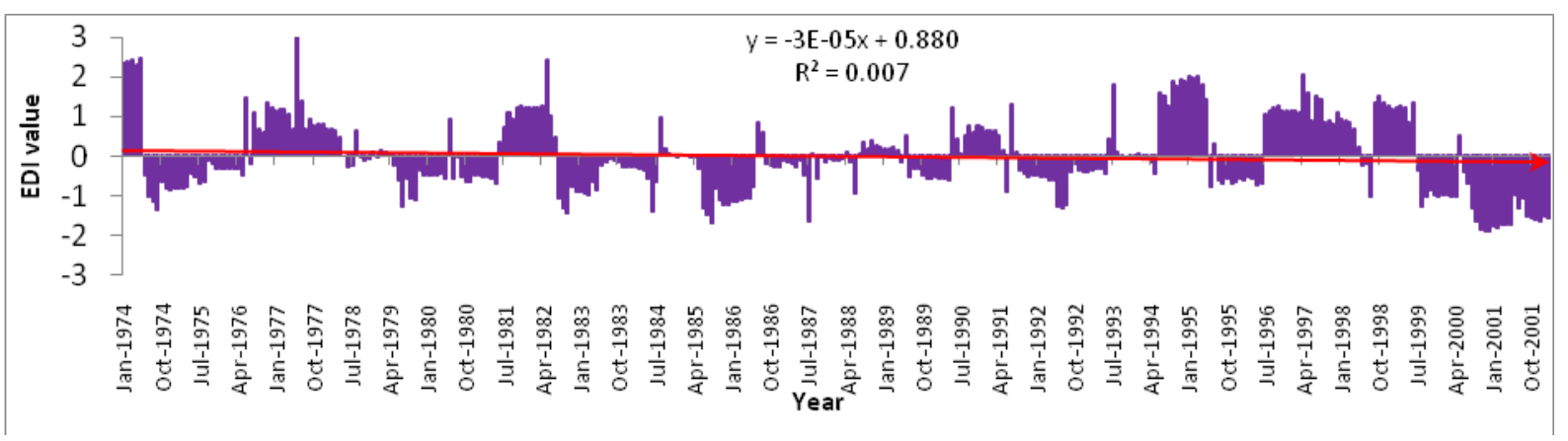

Fig.4 Temporal variation of meteorological drought at Danpur station

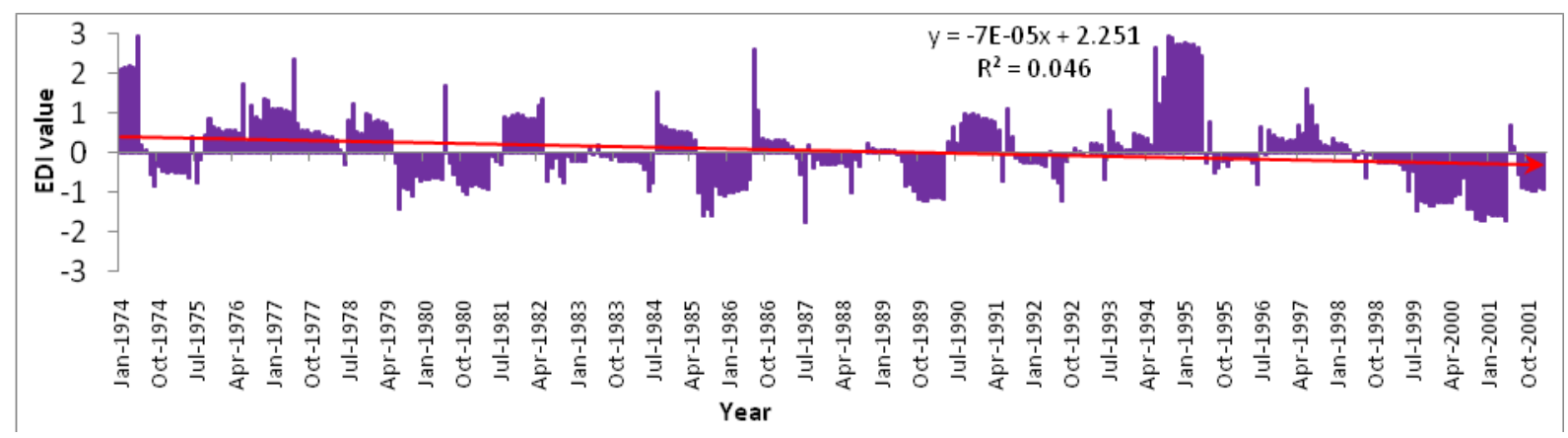


Fig.5 Temporal variation of meteorological drought at Shergarh station

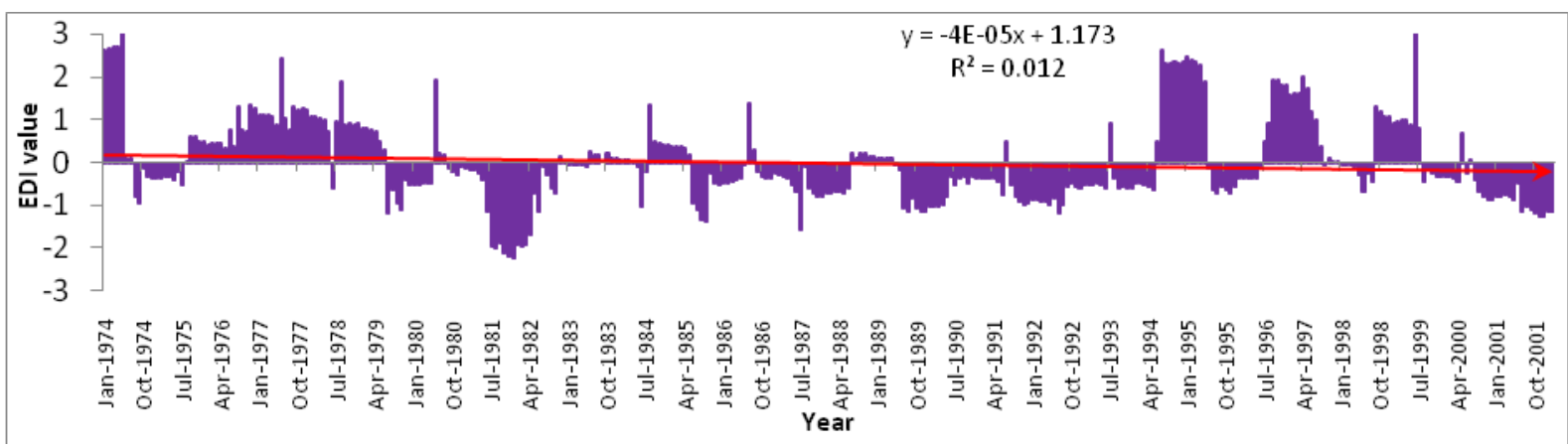

Fig.6 Temporal variation of meteorological drought at Arthuna station

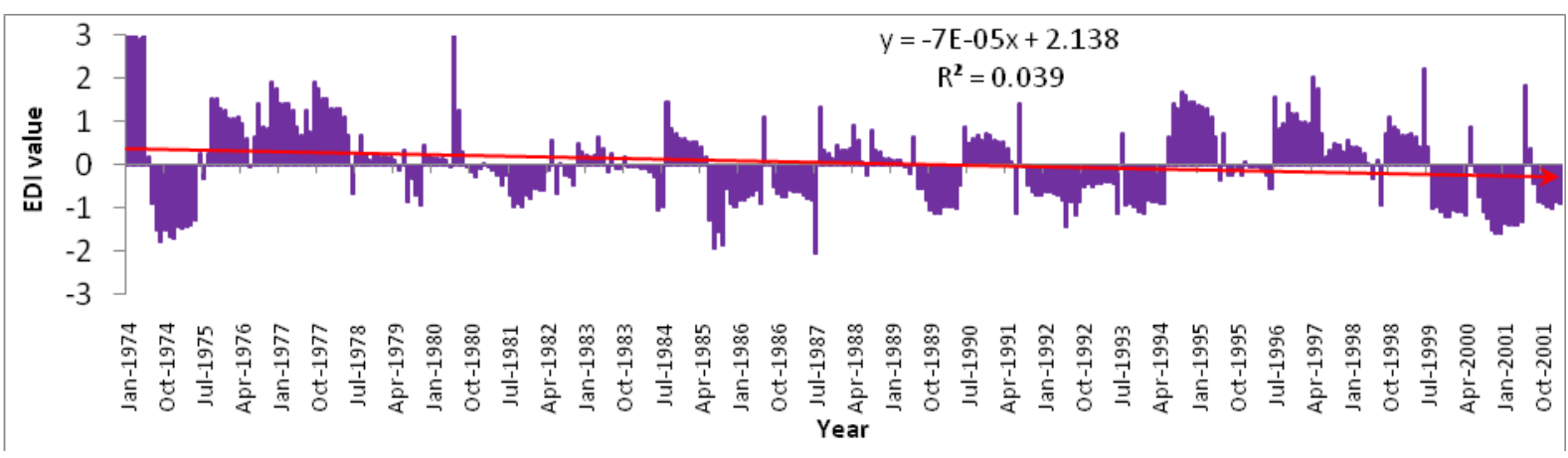

Fig.7 Temporal variation of meteorological drought at Loharia station

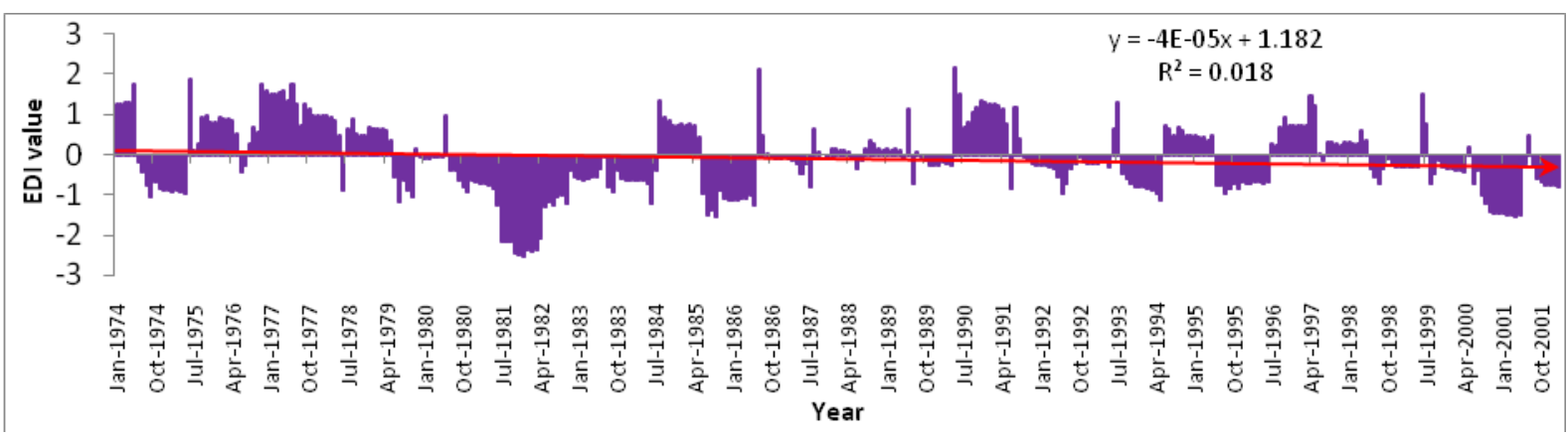

Fig.8 Temporal variation of meteorological drought at Bhungra station

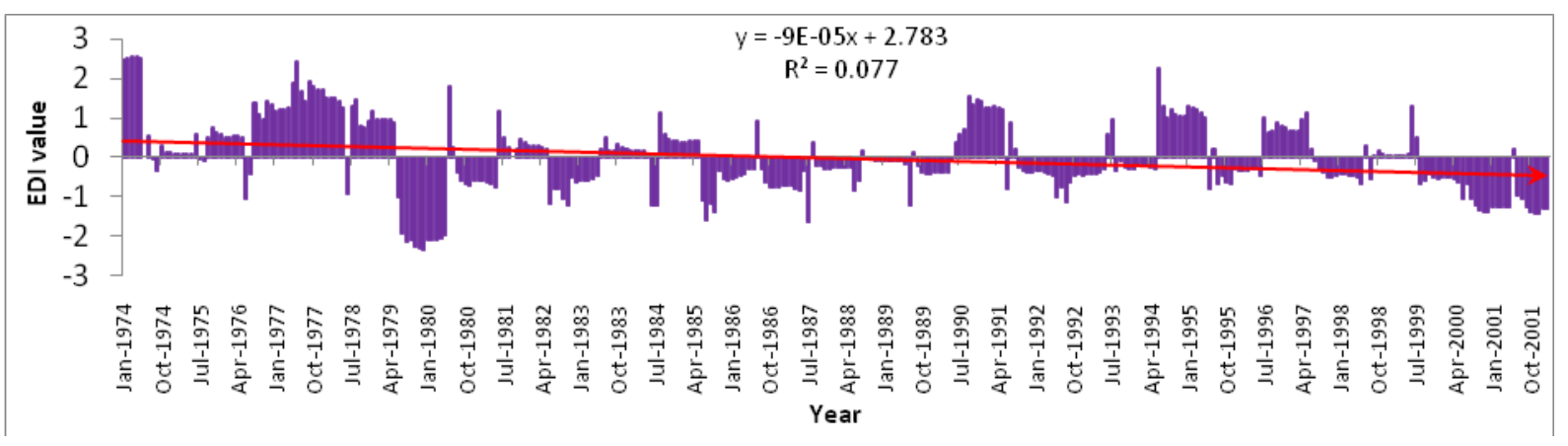


Fig.9 Temporal variation of meteorological drought at Sajjangarh station

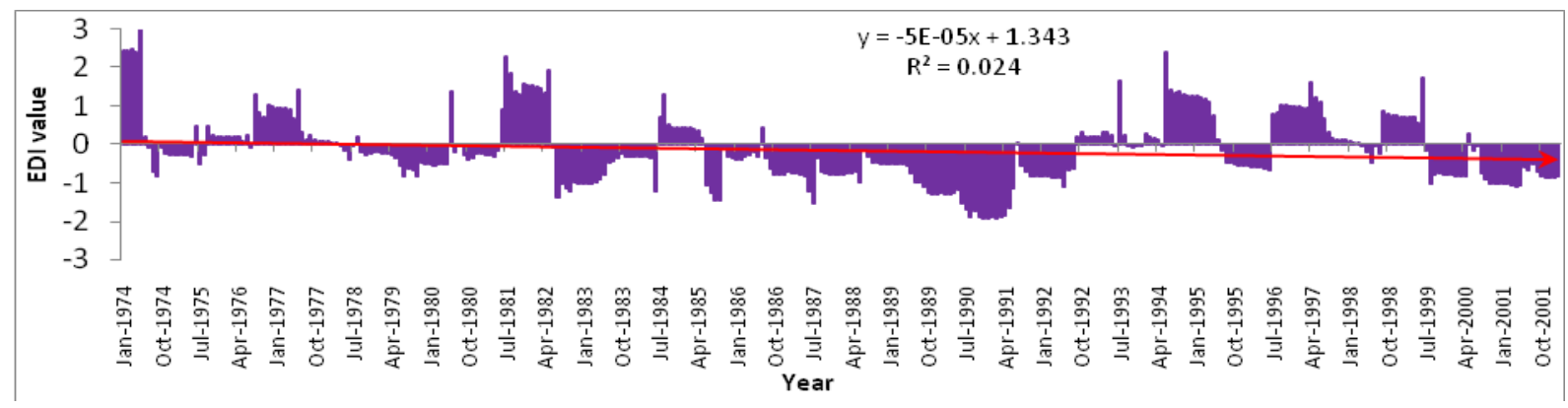

Fig.10 Temporal variation of meteorological drought at Ghatol station

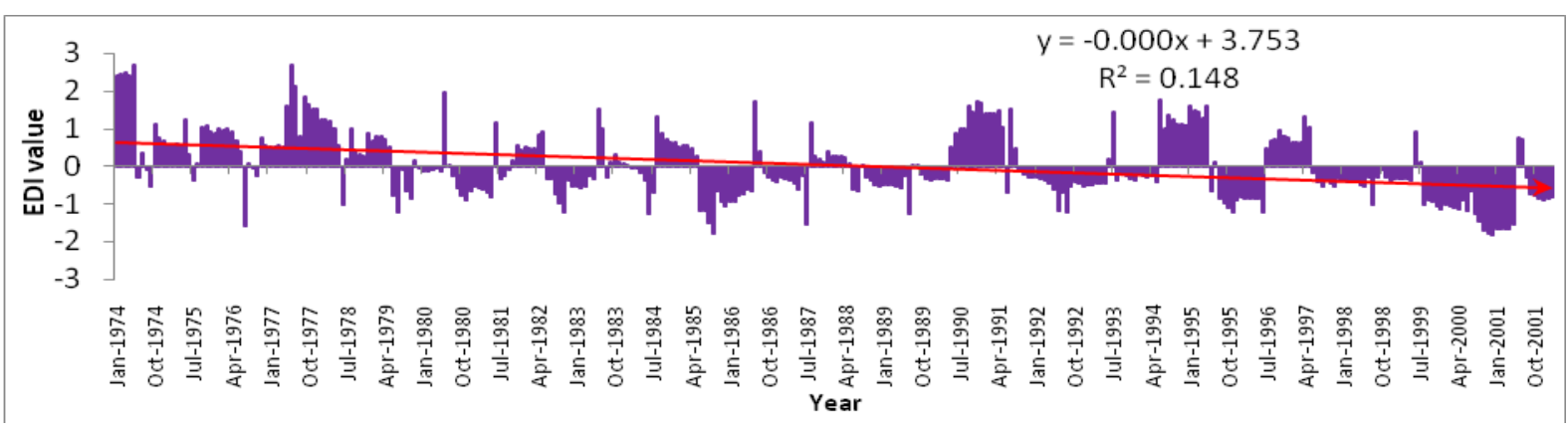

Fig.11 Temporal variation of meteorological drought at Bagidora station

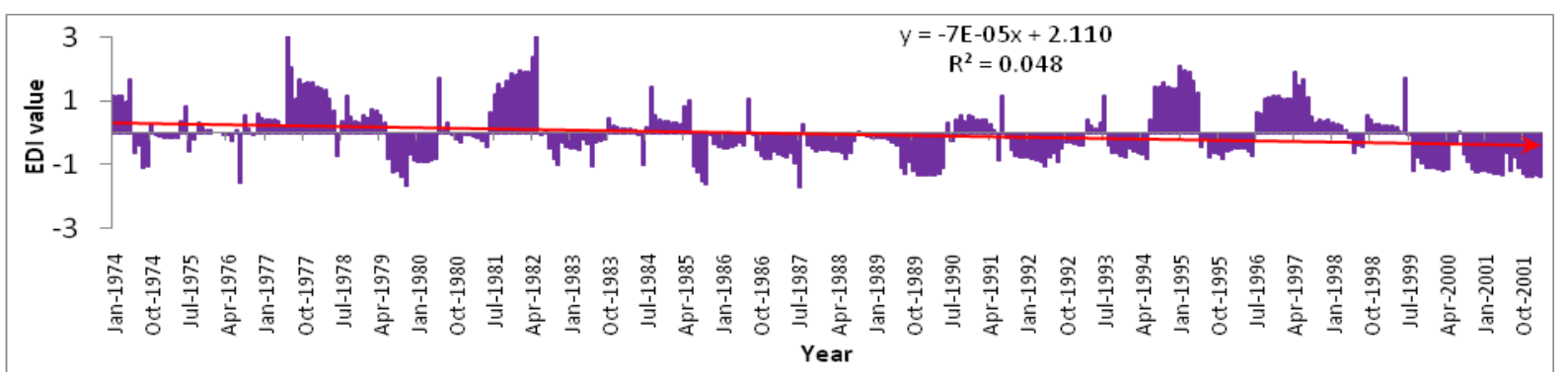

Table.1 Average rainfall data of eleven rain gauge station with latitude and longitude

\begin{tabular}{|c|c|c|c|}
\hline Rain gauge station & Latitude & Longitude & A verage rainfall $(\mathrm{mm})$ \\
\hline Loharia & $23^{0} 46^{\prime} \mathrm{N}$ & $74^{0} 14^{\prime} \mathrm{E}$ & 772.60 \\
\hline Sajjangarh & $23^{0} 15^{\prime} \mathrm{N}$ & $74^{0} 15^{\prime} \mathrm{E}$ & 812.08 \\
\hline Garhi & $23^{0} 36^{\prime} \mathrm{N}$ & $74^{0} 08^{\prime} \mathrm{E}$ & 852.21 \\
\hline Shergarh & $23^{0} 20^{\prime} \mathrm{N}$ & $74^{0} 10^{\prime} \mathrm{E}$ & 825.01 \\
\hline Arthuna & $23^{0} 30^{\prime} \mathrm{N}$ & $74^{0} 05^{\prime} \mathrm{E}$ & 860.88 \\
\hline Kushalgarh & $23^{0} 12^{\prime} \mathrm{N}$ & $74^{0} 27^{\prime} \mathrm{E}$ & 987.52 \\
\hline Bhungra & $23^{0} 41^{\prime} \mathrm{N}$ & $74^{0} 31^{\prime} \mathrm{E}$ & 872.87 \\
\hline Bagidora & $23^{0} 27^{\prime} \mathrm{N}$ & $73^{0} 17^{\prime} \mathrm{E}$ & 914.29 \\
\hline Ghatol & $23^{0} 45^{\prime} \mathrm{N}$ & $74^{0} 25^{\prime} \mathrm{E}$ & 915.23 \\
\hline Danpur & $23^{0} 31^{\prime} \mathrm{N}$ & $74^{0} 43^{\prime} \mathrm{E}$ & 1100.90 \\
\hline Banswara & $23^{0} 33^{\prime} \mathrm{N}$ & $74^{0} 27^{\prime} \mathrm{E}$ & 1113.52 \\
\hline
\end{tabular}


Table.2 Meteorological drought severity classification based on EDI values

\begin{tabular}{|l|l|l|l|}
\hline Drought severity classes & EDI ranges & Drought severity classes & EDI ranges \\
\hline Extreme drought & $\leq-2.00$ & Moderate drought & -1.00 to -1.49 \\
\hline Severe drought & -1.50 to -1.99 & Near normal & -0.99 to 0.99
\end{tabular}

Table.3 EDI based drought events in Banswara district of Rajasthan

\begin{tabular}{|c|c|c|c|c|}
\hline Drought class & Extreme & Severe & Moderate & Total \\
\hline Banswara & 0 & 1 & 52 & 53 \\
\hline Garhi & 0 & 10 & 35 & 45 \\
\hline Kushalgarh & 0 & 19 & 46 & 65 \\
\hline Danpur & 0 & 15 & 47 & 62 \\
\hline Shergarh & 3 & 8 & 31 & 58 \\
\hline Arthuna & 2 & 12 & 44 & 45 \\
\hline Loharia & 10 & 7 & 28 & 49 \\
\hline Bhungra & 9 & 4 & 36 & 47 \\
\hline Sajjangarh & 0 & 13 & 34 & 45 \\
\hline Ghatol & 0 & 12 & 33 & 64 \\
\hline Bagidora & 0 & 5 & 59 & \\
\hline
\end{tabular}

Table.4 EDI based meteorological drought characteristics of Banswara district

\begin{tabular}{|c|c|c|c|c|c|}
\hline Rain gauge station & Onset & Termination & Duration & Severity & Intensity \\
\hline Banswara & July 1985 & Sept 1985 & 3 & -3.84 & -1.28 \\
& Oct 1989 & April 1990 & 7 & -7.40 & -1.06 \\
& Nov 1999 & April 2000 & 6 & -6.33 & -1.06 \\
& Aug 2000 & May 2001 & 10 & -13.72 & -1.37 \\
& Sept 2001 & May 2002 & 9 & -11.27 & -1.25 \\
& July 2002 & May 2003 & 11 & -13.10 & -1.19 \\
& Oct 2008 & Dec 2008 & 3 & -3.20 & -1.07 \\
& Aug 1979 & Oct 1979 & 3 & -3.88 & -1.29 \\
& Jun 1985 & Sept 1985 & 4 & -6.62 & -1.66 \\
& Nov 1985 & Feb 1986 & 4 & -4.4 & -1.10 \\
& May 1992 & Aug 1992 & 4 & -5.18 & -1.30 \\
\hline Garhi & July 2002 & May 2003 & 11 & -14.89 & -1.35 \\
& Oct 2008 & Dec 2008 & 3 & -3.37 & -1.12 \\
\hline Aug 1982 & Oct 1982 & 3 & -3.82 & -1.27 \\
& Jun 1985 & Aug 1985 & 3 & -4.50 & -1.50 \\
& Oct 1985 & May 1986 & 8 & -9.04 & -1.13 \\
& Jun 1992 & Aug 1992 & 3 & -3.85 & -1.28 \\
\hline Aug 2000 & May 2001 & 10 & -17.34 & -1.73 \\
& July 2001 & May 2002 & 11 & -16.32 & -1.48 \\
& July 2002 & May 2003 & 11 & -13.92 & -1.27 \\
& July 2008 & Dec 2008 & 6 & -7.61 & -1.27 \\
\hline
\end{tabular}




\begin{tabular}{|c|c|c|c|c|c|}
\hline \multirow[t]{7}{*}{ Danpur } & Jun 1985 & Sept 1985 & 4 & -5.67 & -1.42 \\
\hline & Nov 1985 & Feb 1986 & 4 & -4.19 & -1.05 \\
\hline & Oct 1989 & April 1990 & 7 & -8.22 & -1.17 \\
\hline & Aug 1999 & Jun 2000 & 11 & -13.89 & -1.26 \\
\hline & Aug 2000 & May 2001 & 10 & -16.08 & -1.61 \\
\hline & July 2002 & May 2003 & 11 & -16.29 & -1.48 \\
\hline & Aug 2008 & Dec 2008 & 5 & -6.31 & -1.26 \\
\hline \multirow[t]{4}{*}{ Shergarh } & Jun 1981 & April 1982 & 11 & -21.02 & -1.91 \\
\hline & July 1985 & Sept 1985 & 3 & -3.82 & -1.27 \\
\hline & Oct 1989 & April 1990 & 7 & -7.38 & -1.05 \\
\hline & July 2001 & May 2002 & 11 & -12.79 & -1.16 \\
\hline \multirow[t]{7}{*}{ Arthuna } & Aug 1974 & May 1975 & 10 & -15.23 & -1.52 \\
\hline & Jun 1985 & Sept 1985 & 4 & -6.63 & -1.66 \\
\hline & Oct 1989 & Dec 1989 & 3 & -3.29 & -1.10 \\
\hline & Oct 1999 & April 2000 & 7 & -7.89 & -1.13 \\
\hline & Aug 2000 & May 2001 & 10 & -13.92 & -1.39 \\
\hline & Oct 2002 & Jan 2003 & 4 & -4.86 & -1.21 \\
\hline & July 2008 & Dec 2008 & 6 & -7.95 & -1.32 \\
\hline \multirow[t]{4}{*}{ Loharia } & Jun 1981 & Oct 1982 & 17 & -31.48 & -1.85 \\
\hline & July 1985 & Sept 1985 & 3 & -4.45 & -1.48 \\
\hline & Nov 1985 & Jun 1986 & 8 & -8.97 & -1.12 \\
\hline & Aug 2000 & May 2001 & 10 & -14.13 & -1.41 \\
\hline \multirow[t]{4}{*}{ Bhungra } & July 1979 & May 1980 & 11 & -23.46 & -2.13 \\
\hline & Jun 1985 & Sept 1985 & 4 & -5.26 & -1.32 \\
\hline & Aug 2000 & May 2001 & 10 & -12.71 & -1.27 \\
\hline & Aug 2001 & May 2002 & 10 & -13.13 & -1.31 \\
\hline \multirow[t]{5}{*}{ Sajjangarh } & July 1982 & Oct 1982 & 4 & -4.77 & -1.19 \\
\hline & Dec 1982 & March 1983 & 4 & -4.09 & -1.02 \\
\hline & Jun 1985 & Sept 1985 & 4 & -5.21 & -1.30 \\
\hline & Sept 1989 & Jun 1991 & 22 & -34.15 & -1.55 \\
\hline & Oct 2000 & May 2001 & 8 & -8.35 & -1.04 \\
\hline \multirow[t]{4}{*}{ Ghatol } & Jun 1985 & Sept 1985 & 4 & -5.67 & -1.42 \\
\hline & Nov 1999 & April 2000 & 6 & -6.56 & -1.09 \\
\hline & Aug 2000 & May 2001 & 10 & -16.26 & -1.63 \\
\hline & Oct 2002 & Jan 2003 & 4 & -5.2 & -1.30 \\
\hline \multirow[t]{8}{*}{ Bagidora } & July 1979 & Oct 1979 & 4 & -5.48 & -1.37 \\
\hline & Jun 1985 & Sept 1985 & 4 & -5.44 & -1.36 \\
\hline & Oct 1989 & May 1990 & 8 & -10.17 & -1.27 \\
\hline & Nov 1999 & April 2000 & 6 & -6.76 & -1.13 \\
\hline & Oct 2000 & May 2001 & 8 & -9.87 & -1.23 \\
\hline & Sept 2001 & May 2002 & 9 & -11.89 & -1.32 \\
\hline & Oct 2002 & May 2003 & 8 & -9.18 & -1.15 \\
\hline & Aug 2008 & Dec 2008 & 5 & -5.62 & -1.12 \\
\hline
\end{tabular}

The drought severity assessment based on the EDI indicates that the maximum drought severity of -34.15 occurred between September 1989 to June 1991 and it was for 
longest duration (22 months) drought in the area under Sajjangarh rain gauge station. The drought having a maximum intensity of -2.13 , occurred from July 1979 to May 1980, with a severity of -23.46 in the area under Bhungra rain gauge station.

The meteorological drought characteristics have been assessed using Effective Drought Index (EDI). According to EDI, a meteorological drought of maximum severity -34.15 occurred for the duration of 22 months from September 1989 to June 1991 which was for longest period in the area falling under Sajjangarh rain gauge station. The drought having a maximum intensity of -2.13 , occurred from July 1979 to May 1980, with a severity of -23.46 in the area under Bhungra rain gauge station. The distribution of extreme drought event varies from maximum 10 in numbers to minimum 2 in numbers at Loharia and Arthuna rain gauge station respectively. A maximum number of 19 severe drought events occur in Kushalgarh and lowest of 1 at Banswara. The maximum moderate drought occurs in 59 at Bagidora and minimum in 28 at Loharia rain gauge station.

The total maximum number of 65 drought event occurs in Kushalgarh and minimum in 42 at Shergarh rain gauge station. The trend of meteorological drought severity is found to be rising regularly. The analysis also indicates that there is least occurrence of extreme droughts and frequent occurrence of moderate droughts in the area during the period of study.

\section{Acknowledgement}

I would like to express my special thanks of gratitude to Mr. Saswat Kumar Kar (Research Scholar, Department of Farm Engineering, Institute of Agricultural Sciences, BHU, Varanasi) for his great cooperation during this work.

\section{References}

Byun, H. R and Kim, D. W., 2010. Comparing the effective drought index and the standardized precipitation index. Economics of Drought and Drought Preparedness in a Climate Change Context, 95: 85-89.

Byun, H. R and Wilhite, D. A., 1999. Objective quantification of drought severity and duration. Journal of Climate, 12(9): 2747-2756.

Dutta, D., Kundu, A., Patel, N. R., Saha, S. K and Siddiqui, A. R., 2015. Assessment of agricultural drought in Rajasthan (India) using remote sensing derived Vegetation Condition Index (VCI) and Standardized Precipitation Index (SPI). The Egyptian Journal of Remote Sensing and Space Science, 18(1): 5363.

Gupta, A. K., Tyagi, P and Sehgal, V. K., 2011. Drought disaster challenges and mitigation in India: strategic appraisal, Current Science, 100(12): 1795-1806.

Jain, S. K., Keshri, R., Goswami, A and Sarkar, A., 2010. Application of meteorological and vegetation indices for evaluation of drought impact: a case study for Rajasthan, India. Natural Hazards, 54(3): 643-656.

Kar, S. K., Thomas, T and Singh, R. M., 2016. Assessment of drought characteristics for Dhasan basin in Bundelkhand region. International Journal of Agriculture, Environment and Biotechnology, 9(5): 897.

Kar., S. K., 2016. Integrated assessment of drought vulnerability for Dhasan basin in Madhya Pradesh. Thesis M. Tech. (Ag). Banaras Hindu University, Institute of Agricultural Sciences, Department of Farm Engineering, Varanasi, UP, India.

Manual for drought management, National Institute of Disaster Management 
(NIDM), Department of Agriculture, Government of India, New Delhi. (2009). 1-102.

Morid, S., Smakhtin, V and Moghaddasi, M., 2006. Comparison of seven meteorological indices for drought monitoring in Iran. International Journal of Climatology, 26(7): 971-985.

Pandey, R. P., Dash, B. B., Mishra, S. K and Singh, R., 2008. Study of indices for drought characterization in $\mathrm{KBK}$ districts in Orissa (India), Hydrological Processes, 22(12): 1895-1907.

Sigdel, M and Ikeda, M., 2010. Spatial and Temporal Analysis of Drought in Nepal using Standardized Precipitation Index and its Relationship with Climate Indices, Journal of Hydrology and Meteorology, 7(1): 59-74.

Wilhite, D and Knutson, C. L., 2008. Drought management planning: Conditions for success, Options Méditerranéennes Series A, 80, 141-148.

\section{How to cite this article:}

Chandra Kishor Kumar, V.K. Chandola and Ranjeet Kumar. 2018. Meteorological Drought Characterization Using Effective Drought Index (EDI) for Banswara District (Rajasthan), India. Int.J.Curr.Microbiol.App.Sci. 7(09): 3407-3416. doi: https://doi.org/10.20546/ijcmas.2018.709.423 